\title{
Melalui Pendekatan Saintifik Model Pembelajaran Abad Ke-21 Metode Blended Learning untuk Meningkatkan Hasil Belajar Peserta Didik Mata Pelajaran Matematika Kd 3.2/4.2 Pokok Bahasan Sistem Persamaan Linear Tiga Variabel di Kelas X.IS.1 MAN 2 Kota Payakumbuh Semester Ganjil Tahun Pelajaran 2021/2022
}

\author{
Dewi Kemala \\ MAN 2 Kota Payakumbuh \\ J1. Tj. Gadang, Kec. Payakumbuh Bar., Kota Payakumbuh, Sumatera Barat, Indonesia \\ dewi_kemala@gmail.com
}

\begin{abstract}
This study is aimed to see and analyze the increasing of students learning result of mathematic subject in basic competency 3.2/3.4 about linear equation system three variables applying scientific approach the 21st century learning learning model in covid-19 pandemic learning at tenth grade, even semester of MAN 2 Payakumbuh, west Sumatra.This research was applying classroom action research. It consisted of two cycles where each cycle consisted of planning, action, reflection, and evaluation. This research has been conducted from august to November 2021. The data was processed and analyzed into percentage. The improvement in the average value of learning result for knowledge competence at the 1st cycle from 79,72 to 84,17 at the 2nd cycle and the result value for skill competences increased from 77,78 at the 1 st cycle to 80,56 at the 2 nd cycle. The students learning mastery for knowledge competence at the 1 st cycle and the 2 nd cycle is 32 students $(88,89 \%)$ for skill competence have increased from 24 students $(66,67 \%)$ at the 1 st cycle become 33 students $(91,67 \%)$ at the 2nd cycle from 36 students. The conclusion obtained from this research is the applying scientific approach the $21 \mathrm{st}$ century learning model in covid-19 pandemic learning can improved the students learning result.
\end{abstract}

Keywords: Learning Outcomes, Skills and Learning Models with Scientific Approach

\begin{abstract}
Abstrak
Penelitian ini bertujuan untuk melihat dan menganalisis peningkatan hasil belajar siswa mata pelajaran matematika pada kompetensi dasar 3.2/3.4 tentang sistem persamaan linear tiga variabel yang menerapkan pendekatan saintifik model pembelajaran abad 21 pada pembelajaran pandemi covid-19 kelas X, semester genap. MAN 2 Payakumbuh, Sumatera Barat. Penelitian ini merupakan penelitian tindakan kelas. Terdiri dari dua siklus dimana setiap siklus terdiri dari perencanaan, tindakan, refleksi dan evaluasi. Penelitian ini dilaksanakan pada bulan Agustus sampai dengan November 2021. Data diolah dan dianalisis menjadi persentase. Peningkatan nilai rata-rata hasil belajar kompetensi pengetahuan pada siklus I dari 79,72 menjadi 84,17 pada siklus II dan nilai hasil belajar kompetensi keterampilan meningkat dari 77,78 pada siklus I menjadi 80,56 pada siklus I. siklus ke-2. Ketuntasan belajar siswa untuk kompetensi pengetahuan pada siklus I dan siklus II adalah 32 siswa $(88,89 \%)$ untuk kompetensi keterampilan mengalami peningkatan dari 24 siswa $(66,67 \%)$ pada siklus I menjadi 33 siswa $(91,67 \%)$. ) pada siklus II dari 36 siswa. Kesimpulan yang diperoleh dari penelitian ini adalah penerapan pendekatan saintifik model pembelajaran abad 21 dalam pembelajaran pandemi covid-19 dapat meningkatkan hasil belajar siswa.
\end{abstract}

Kata kunci: Hasil Belajar, Keterampilan dan Model Pembelajaran Pendekatan Saintifik

Copyright (c) 2021 Dewi Kemala

Corresponding author: Dewi Kemala

Email Address: dewi_kemala@gmail.com (Jl. Tj. Gadang, Kota Payakumbuh, Sumatera Barat, Indonesia)

Received 10 January 2022, Accepted 20 January 2022, Published 21 January 2022

\section{PENDAHULUAN}

Hingga saat ini, sebagian besar dunia masih mengalami masa pandemi virus corona atau COVID 19. Semua sektor kehidupan diatur sesuai dengan protocol Kesehatan termasuk sector Pendidikan. Pendidikan di Indonesia masih menggunakan pembelajaran Covid 19. Matematika sebagai salah satu ilmu pengetahuan yang memiliki peranan penting dalam pendidikan. Matematika 
Melalui Pendekatan Saintifik Model Pembelajaran Abad Ke-21 Metode Blended Learning untuk Meningkatkan Hasil Belajar Peserta Didik Mata Pelajaran Matematika Kd 3.2/4.2 Pokok Bahasan Sistem Persamaan Linear Tiga Variabel Di Kelas X.IS.1 Man 2 Kota Payakumbuh Semester Ganjil Tahun Pelajaran 2021/2022, Dewi Kemala

juga merupakan ilmu pengetahuan yang mendasari perkembangan teknologi modern dan ilmu-ilmu eksak lainnya. Teknologi tidak dapat berkembang jika tidak ada yang menguasai matematika. Begitu pula dengan ilmu pengetahuan lainnya, penerapan konsep matematika menyebabkan ilmu pengetahuan eksak dan ilmu lainnya berkembang. Banyak ilmu-ilmu lainnya yang penemuan dan pengembangannya diperoleh dari konsep matematika. Tidak hanya dalam teknologi dan ilmu pengetahuan lainnya, konsep matematika digunakan dalam kehidupan sehari-hari. Dalam memecahkan suatu masalah dalam kehidupan, sering sekali kita menggunakan konsep dan pemecahan masalah matematika. Dalam aktivitas sehari-hari, baik disadari maupun tidak kita pasti menggunakan matematika. Dengan demikian, matematika merupakan salah satu mata pelajaran yang sangat penting dipelajari disetiap jenjang pendidikan hingga ke perguruan tinggi.

Penulis sebagai salah seorang guru mata pelajaran Matematika di kelas X MAN 2 Payakumbuh pada awal semester ganjil Tahun Pelajaran 2021/2022 melihat adanya masalah dan fenomena dalam proses pembelajaran di masa pandemic Covid 19. Masalah atau fenomena yang ditemukan adalah masih rendahnya hasil belajar peserta didik. Hal ini dapat dilihat diantaranya dari hasil ulangan harian peserta didik pada materi pokok sebelum dilaksanakan penelitian.

Berdasarkan observasi awal dan didukung oleh data bahwa kelas X IS 1 memiliki nilai ratarata paling rendah dari kelas yang lain, yaitu dengan nilai rata-rata pengetahuan 67 dan nilai rata-rata keterampilan 69. Peserta yang tuntas pada aspek pengetahuan sebanyak 9 orang dan aspek keterampilan sebanyak 18 orang. Sedangkan peserta yang tidak tuntas pada aspek pengetahuan sebanyak 28 orang dan aspek keterampilan sebanyak 20 orang.

Menyikapi kondisi tersebut diatas penulis mencoba menggunakan model pembelajaran abad ke-21 metode Blended Learning. Metode Pembelajaran Blended Learning mempunyai tujuan utama untuk memberikan pelatihan kepada peserta untuk lebih bisa bekerjasama yang efektif, saling memberikan informasi, serta mendengar dan menggunakan ide-ide orang lain, sesuai dengan tuntutan abad ke-21. Metode pembelajaran Blended Learning adalah pembelajaran yang menggabungkan metode daring dan tatap muka.

Sehubungan dengan itu penulis tertarik untuk mengetahui apakah strategi ini dapat meningkatkan penguatan karakter dan hasil belajar peserta didik kelas X IS 1 MAN 2 Kota Payakumbuh. Penulis akan mengadakan penelitian dalam bentuk Penelitian Tindakan Kelas dengan judul "Melalui Peningkatan Saintifik Model Pembelajaran Abad ke-21 Metode Blended Learning untuk Meningkatkan Hasil Belajar Tingkat Mata Pelajaran Matematika Wajib KD 3.2/4.2 Pokok Bahasan Sistem Persamaan Linear Tiga Variabel di Kelas X IS 1 MAN 2 Kota Payakumbuh Semester Ganjil Tahun Pelajaran 2021/2022”.

\section{METODE}

Penelitian ini adalah penelitian tindakan kelas (PTK). Rancangan penelitian yang menggunakan empat langkah yaitu: Perencanaan (planning), Tindakan (action), Observasi 
(observation), Refleksi/evaluasi (reflection). Subjek penelitian adalah peserta didik kelas X IS 1 MAN 2 Kota Payakumbuh yang berjumlah 36 orang peserta didik. Penelitian ini dilaksanakan di MAN 2 Kota Payakumbuh yang beralamat di Jalan Soekarno Hatta, Koto Nan Ampek, Kecamatan Payakumbuh Barat, Kota Payakumbuh. Waktu penelitian dilaksanakan selama empat bulan yang berlangsung selama bulan Agusutus sampai dengan November 2021 di semester ganjil Tahun Pelajaran. 2021/2022. Instrumen penelitian adalah alat atau fasilitas yang digunakan oleh peneliti untuk mengumpulkan data penelitian. Instrumen ini terdiri dari Observasi, Tes Hasil Belajar, Instrumen. Hasil observasi dianalisis dengan metode analisis deskriptif komparatif teknik presentatif.

\section{HASIL DAN DISKUSI}

\section{Prasiklus}

\section{Pengetahuan}

Nilai pengetahuan prasiklus yang diambil dari Penilaian Harian 1 dapat dilihat pada lampiran. Hasil pengolahan perolehan nilai dapat dilihat pada table berikut.

Tabel 1. Hasil Pengolahan Nilai Pengetahuan Prasiklus

\begin{tabular}{|c|l|c|}
\hline No & \multicolumn{1}{|c|}{ Uraian } & Frekuensi \\
\hline 1. & Peserta & 36 \\
\hline 2. & Peserta didik yang tuntas & 13 \\
\hline 3. & Peserta didik yang tidak tuntas & 23 \\
\hline 4. & Nilai rata-rata kelas & 67,08 \\
\hline 5. & Persentase ketuntasan & 36,11 \\
\hline
\end{tabular}

Berdasarkan nilai pengetahuan pra siklus pada table 4.2 terlihat bahwa, dari 36 orang peserta didik yang mengikuti tes, 23 peserta didik atau $63,88 \%$ belum mencapai batas ketuntasan $\geq 75$, sedangkan yang mencapai batas ketuntasan sebanyak 13 peserta didik atau 36,11\% dan perolehan nilai rata-rata kelas 67,08. Hasil pengolahan nilai pengetahuan ini dapat dilihat pada grafik 1. berikut:

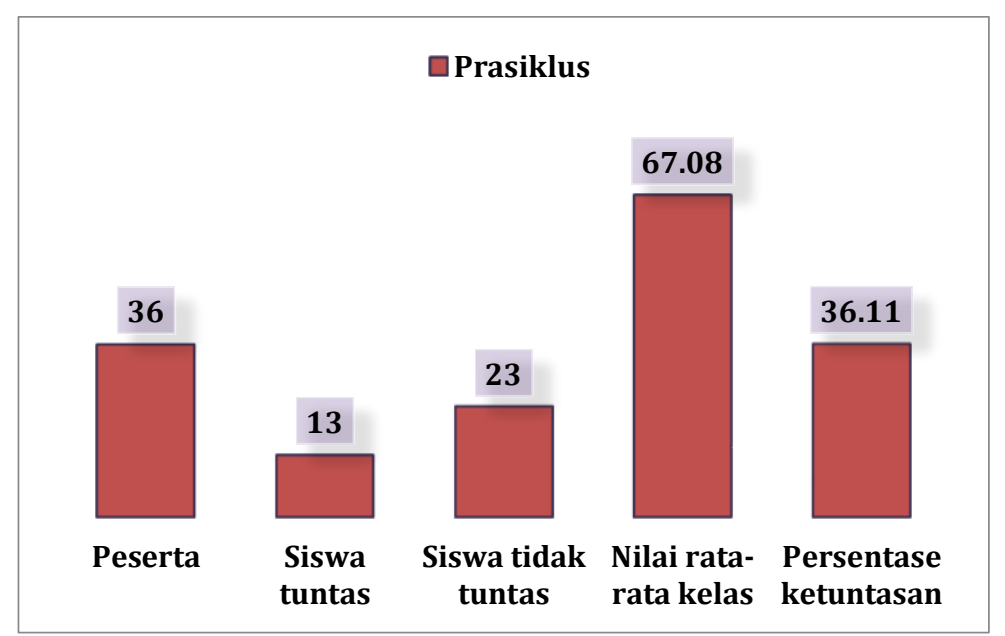

Gambar 1. Nilai Pengetahuan Prasiklus 
Melalui Pendekatan Saintifik Model Pembelajaran Abad Ke-21 Metode Blended Learning untuk Meningkatkan Hasil Belajar Peserta Didik Mata Pelajaran Matematika Kd 3.2/4.2 Pokok Bahasan Sistem Persamaan Linear Tiga Variabel

\section{Keterampilan}

Nilai keterampilan prasiklus yang diambil dari Penilaian Harian 2 dapat dilihat pada lampiran. Hasil pengolahan nilai dapat dilihat pada table berikut.

Tabel 2. Hasil Pengolahan Nilai Keterampilan Pra Siklus

\begin{tabular}{|c|c|c|}
\hline No & Uraian & Frekuensi \\
\hline 1. & Peserta & 36 \\
\hline 2. & peserta didik yang tuntas & 11 \\
\hline 3. & peserta didik yang tidak tuntas & 25 \\
\hline 4. & Nilai rata-rata kelas & 69,72 \\
\hline 5. & Persentase ketuntasan & 30,56 \\
\hline
\end{tabular}

Tabel 2. di atas menunjukkan bahwa, dari 36 peserta didik yang mengikuti tes, 25 peserta didik atau 69,44\% tidak tuntas, sedangkan 11 peserta didik atau 30,56\% tuntas. Perolehan nilai rata-rata kelas 69,72. Hasil pengolahan nilai di atas dapat dilihat pada grafik 2 berikut:

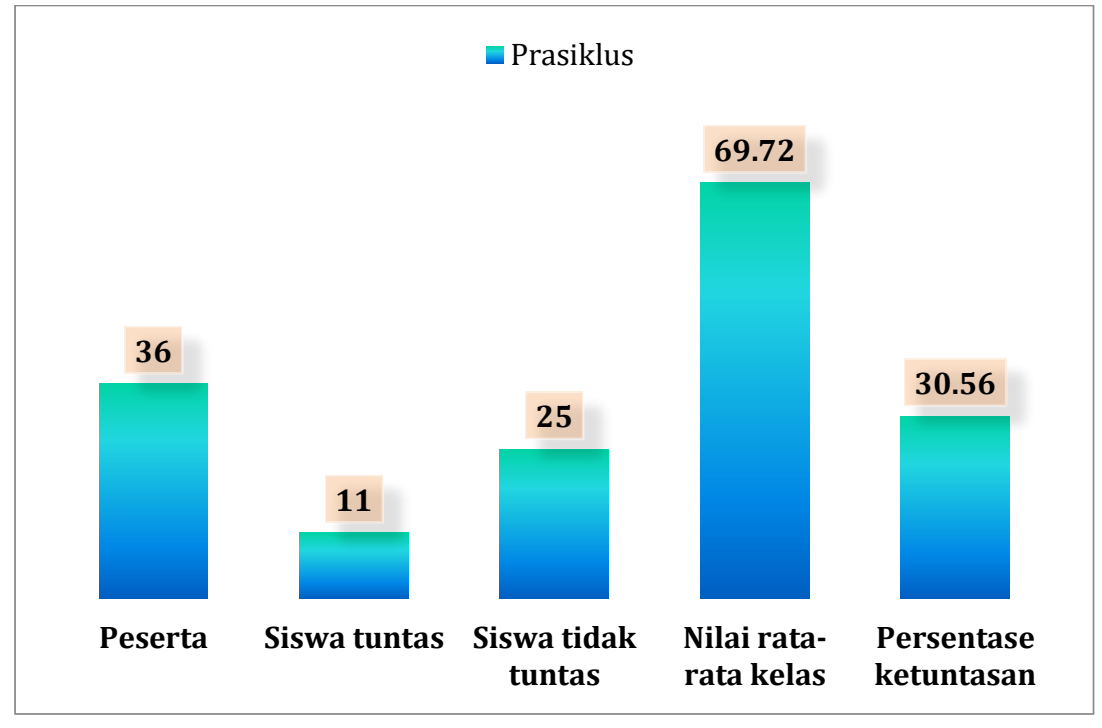

Gambar 2. Nilai Keterampilan Prasiklus

Berdasarkan perolehan nilai prasiklus dapat disimpulkan bahwa penggunaan metode konvensional yaitu ceramah dan tanya jawab mengakibatkan peserta didik kurang memahami materi secara keseluruhan. Rencana penelitian selanjutnya adalah menerapkan model pembelajaran Abad ke-21 metode Blended Learning. Adapun yang akan penulis lakukan antara lain adalah:

1. Menggunakan model pembelajaran Blended learning yang diterapkan kepada peserta didik untuk meningkatkan hasil belajarnya.

2. Mengadakan refleksi pada setiap pertemuan untuk mengukur keberhasilan pembelajaran setiap pertemuan.

\section{Hasil Pelaksanaan Siklus I}

\section{Perencanaan}


Kegiatan siklus I akan dilaksanakan enam pertemuan. Pertemuan ke-1, ke-2, ke-3, ke-4, ke-5, ke-6 dan penilaian (tes) siklus I pada pertemuan ke-7. Sebelum melakukan Tindakan, penulis terlebih dahulu mempersiapkan segala sesuatu yang diperlukan dalam penelitian ini, diantaranya adalah: Silabus Pembelajaran dan Rencana Pelaksanaan Pembelajaran (RPP) yang disesuaikan dengan rencana Tindakan.

\section{Pelaksanaan Tindakan}

Pelaksanaan Tindakan dilakukan pada siklus I yang terdiri dari enam pertemuan. Pertemuan 1 dilakukan pada hari Kamis tanggal 26 Agustus 2021, pertemuan 2 pada hari Jumat tanggal 27 Agustus 2021, pertemuan 3 pada hari Kamis tanggal 2 September 2021 dan pertemuan 4 pada hari Jumat tanggal 3 September 2021, pertemuan 5 pada hari Kamis 9 September 2021, pertemuan 6 Jumat tanggal 10 September 2021.Dengan penilaian siklus 1 Kamis tgl 16 September 2021.

\section{Observasi}

\section{Pengetahuan}

Nilai pengetahuan yang diperoleh peserta didik setelah penilaian siklus I dapat dilihat pada lampiran. Hasil pengolahan perolehan nilai tersebut dapat dilihat pada table berikut.

Tabel 3. Hasil Pengolahan Perolehan Nilai Pengetahuan Siklus I

\begin{tabular}{|c|l|c|c|}
\hline \multirow{2}{*}{ No } & \multicolumn{1}{|c|}{ Uraian } & \multicolumn{2}{c|}{ Frekuensi } \\
\cline { 3 - 4 } & & Prasiklus & Siklus I \\
\hline 1 & Peserta & 36 & 36 \\
\hline 2 & Peserta didik tuntas & 23 & 25 \\
\hline 3 & Peserta didik tidak tuntas & 67,08 & 11 \\
\hline 4 & Nilai rata-rata kelas & 36,11 & 69,72 \\
\hline 5 & Persentase ketuntasan & \\
\hline
\end{tabular}

Berdasarkan nilai pengetahuan yang diperoleh peserta didik pada siklus I terlihat bahwa, dari 36 peserta didik yang mengikut, 11 peserta didik atau 30,56\% tidak tuntas, sedangkan 25 peserta didik atau $69,44 \%$ telah tuntas, dan nilai rata-rata kelas 69,44 . Hasil pengolahan nilai pengetahuan ini dapat dilihat pada Grafik 3 berikut:

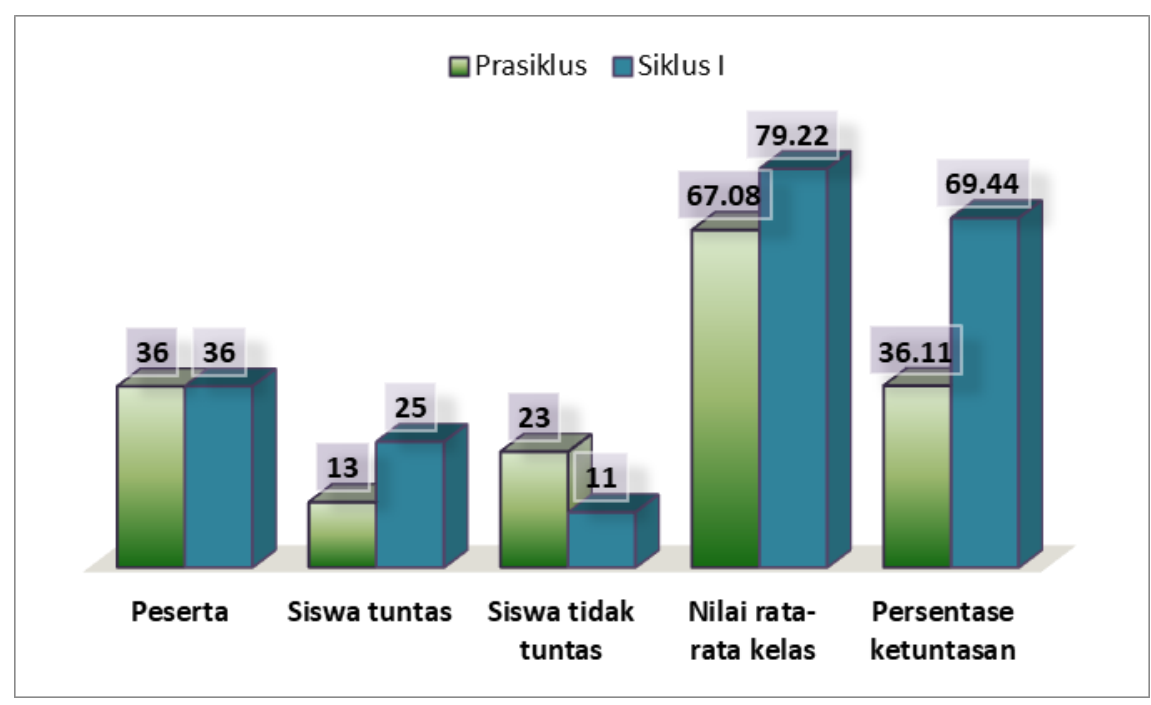


Melalui Pendekatan Saintifik Model Pembelajaran Abad Ke-21 Metode Blended Learning untuk Meningkatkan Hasil Belajar Peserta Didik Mata Pelajaran Matematika Kd 3.2/4.2 Pokok Bahasan Sistem Persamaan Linear Tiga Variabel Di Kelas X.IS.1 Man 2 Kota Payakumbuh Semester Ganjil Tahun Pelajaran 2021/2022, Dewi Kemala

Gambar 3. Nilai Pengetahuan Siklus I

\section{Keterampilan}

Nilai keterampilan yang diperoleh peserta didik setelah penilaian siklus I dapat dilihat pada lampiran. Hasil pengolahan perolehan nilai tersebut dapat dilihat pada tabel berikut:

\section{Tabel 4. Hasil Pengolahan Perolehan Nilai Keterampilan Siklus I}

\begin{tabular}{|c|l|c|c|}
\hline \multirow{2}{*}{ No } & \multicolumn{1}{|c|}{ Uraian } & \multicolumn{2}{c|}{ Frekuensi } \\
\cline { 3 - 4 } & & Prasiklus & Siklus I \\
\hline 1 & Peserta & 36 & 36 \\
\hline 2 & Peserta didik tuntas & 11 & 24 \\
\hline 3 & Peserta didik tidak tuntas & 25 & 12 \\
\hline 4 & Nilai rata-rata kelas & 69,72 & 77,78 \\
\hline 5 & Persentase ketuntasan & 30,56 & 66,67 \\
\hline
\end{tabular}

Berdasarkan table 4.8 terlihat bahwa, dari 36 peserta didik yang mengikuti, 12 peserta didik atau $33,33 \%$ tidak tuntas dan 24 peserta didik atau 66,67\% sudah tuntas, dan nilai rata-rata kelas 66,67. Hasil pengolahan nilai pengetahuan ini dapat dilihat pada gambar 4. berikut.

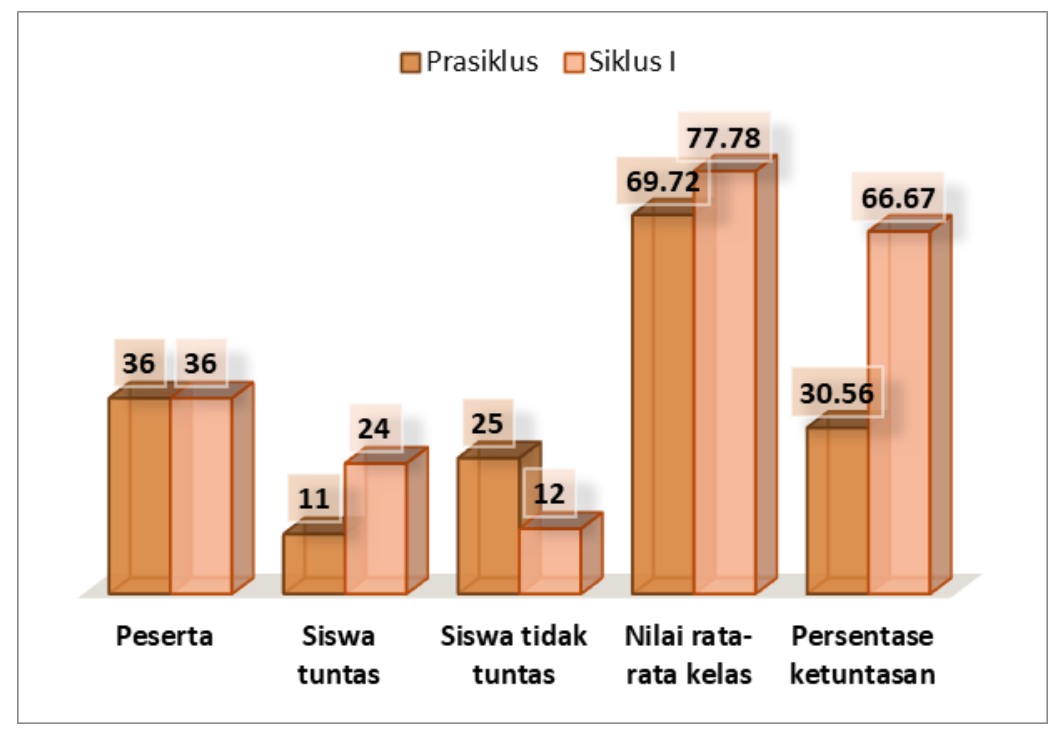

Gambar 4. Nilai Keterampilan Siklus I

Berdasarkan perolehan nilai prasiklus dan siklus I menunjukkan adanya peningkatan hasil belajar peserta didik. Untuk nilai pengetahuan persentase peserta didik yang tuntas meningkat dari $36,11 \%$ pada prasiklus menjadi $69,44 \%$ pada siklus I. Untuk nilai keterampilan persentase peserta didik yang tuntas $30,56 \%$ pada prasiklus menjadi $66,67 \%$ pada siklus I. sebaliknya peserta didik yang tidak tuntas persentasenya menurun. Perolehan hasil siklus I menunjukkan bahwa implementasi pembelajaran model Abad 21 metode Blended Learning cukup efektif untuk meningkatkan hasil belajar matematika. Namun kenaikan ketuntasan ini belum signifikan, masih perlu dilakukan siklus II.

\section{Refleksi}


Kegiatan pada siklus I menunjukkan tidak ada permasalahan dalam perumusan Rencana Pelaksanaan Pembelajaran (RPP). Jadwal pertemuan telah sesuai dengan kebutuhan pelaksanaan pembelajaran. Sedangkan pada tahap pelaksanaan Tindakan terdapat beberapa kekurangan. Kekurangan-kekurangan pada siklus I disebabkan karena adanya kendala-kendala saat melakukan Tindakan. Kendala yang peneliti hadapi dan rencana perbaikan siklus II dapat dilihat pada table berikut:

Tabel 5. Kendala Tindakan Siklus I dan Rencana Perbaikan Siklus II

\begin{tabular}{|l|l|l|}
\hline No & \multicolumn{1}{|c|}{ Kendala Siklus I } & \multicolumn{2}{|c|}{ Rencana Perbaikan Siklus II } \\
\hline 1 & $\begin{array}{l}\text { Kondisi peserta didik belum } \\
\text { terkendali saat mengerjakan } \\
\text { LKPD }\end{array}$ & $\begin{array}{l}\text { Guru merancang lembar } \\
\text { observasi kelompok untuk } \\
\text { memotivasi peserta didik agar } \\
\text { dapat mengerjakan LKPD } \\
\text { dengan baik. }\end{array}$ \\
\hline 2 & $\begin{array}{l}\text { Peserta didik belum berani } \\
\text { memberikan pendapat atas kerja } \\
\text { temannya. }\end{array}$ & $\begin{array}{l}\text { Bersama peserta didik guru } \\
\text { membahas hasil pekerjaan } \\
\text { peserta didik lainnya dan } \\
\text { meminta mereka memberikan } \\
\text { tanggapan. }\end{array}$ \\
\hline 3 & $\begin{array}{l}\text { Sebagian peserta didik kurang } \\
\text { disiplin mengikuti pembelajaran }\end{array}$ & $\begin{array}{l}\text { Guru harus lebih } \\
\text { memperhatikan disiplin peserta } \\
\text { didik dalam mengikuti } \\
\text { pembelajaran. }\end{array}$ \\
\hline 4 & $\begin{array}{l}\text { Perolehan hasil belajar peserta } \\
\text { didik pada akhir siklus I yang } \\
\text { mencapai KKM masih 69,44\% }\end{array}$ & $\begin{array}{l}\text { Guru memberikan review } \\
\text { sebelum peserta didik } \\
\text { melakukan tes akhir siklus II. }\end{array}$ \\
\hline
\end{tabular}

\section{Hasil Pelaksanaan Siklus II}

\section{Perencanaan}

Pada tahap perencanaan pembelajaran siklus II, Tindakan yang dilakukan hampir sama dengan pembelajaran siklus I. Adapun rancangan Tindakan yang akan penulis lakukan antara lain adalah sebagai berikut: Menyusun rencana pelaksanaan pembelajaran (RPP) tentang sifat-sifat himpunan. Membuat tugas peserta didik berupa LKPD. Menyusun kisi-kisi soal tes siklus II. Menyusun soal tes siklus II berupa soal uraian.

\section{Tindakan}

Peneliti melaksanakan Tindakan siklus II sesuai dengan RPP II yang telah disusun. Pelaksanaan Tindakan siklus II ini terdiri dari 4 kali pertemuan. Pertemuan 1 dilaksanakan pada hari Jum'at tanggal 17 September 2021, pertemuan 2 dilaksanakan pada hari Kamis tangga 23 September 2021, pertemuan 3 dilaksanakan pada hari Jum'at tanggal 24 September 2021 dan pertemuan 4 dilaksanakan pada hari Kamis tanggal 30 September 2021.

\section{Pengamatan}

Nilai pengetahuan yang diperoleh peserta didik setelah penilaian siklus I dapat dilihat pada lampiran. Hasil pengolahan perolehan nilai tersebut dapat dilihat pada tabel berikut. 
Tabel 6. Hasil Pengolahan Nilai Pengetahuan Siklus II

\begin{tabular}{|c|l|c|c|}
\hline \multirow{2}{*}{ No } & \multicolumn{1}{|c|}{ Uraian } & \multicolumn{2}{c|}{ Frekuensi } \\
\cline { 3 - 4 } & & Siklus I & Siklus II \\
\hline 1 & Peserta & 25 & 36 \\
\hline 2 & Peserta didik tuntas & 11 & 32 \\
\hline 3 & Peserta didik tidak tuntas & 79,72 & 84,17 \\
\hline 4 & Nilai rata-rata kelas & 69,44 & 88,89 \\
\hline 5 & Persentase ketuntasan & \multicolumn{2}{c}{} \\
\hline
\end{tabular}

Berdasarkan perolehan nilai pengetahuan siklus II pada table 4.11 terlihat bahwa dari 36 peserta didik yang mengikuti ujian, 4 peserta didik atau $11,11 \%$ tidak tuntas dan 34 peserta didik atau 88,89\% tuntas, dan nilai rata-rata kelas 84,17. Hasil pengolahan nilai diatas dapat dilihat pada grafik 5 berikut.

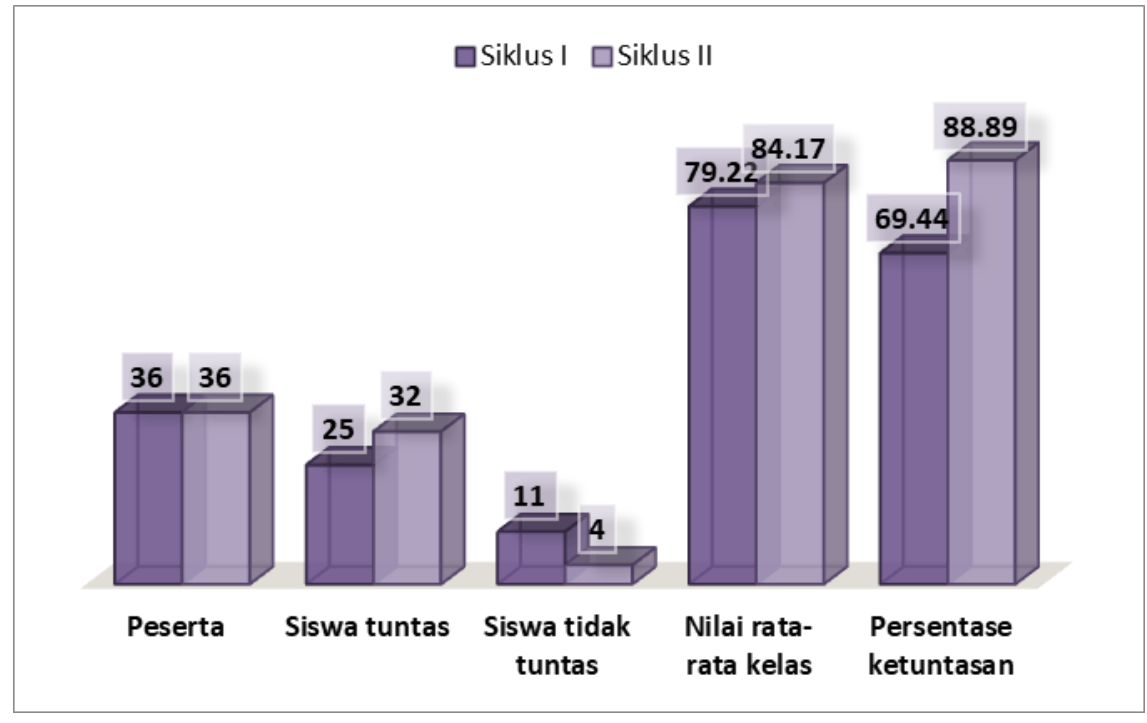

Gambar 5. Nilai Pengetahuan Siklus II

\section{Keterampilan}

Nilai keterampilan yang diperoleh peserta didik setelah penilaian siklus I dapat dilihat pada lampiran. Hasil pengolahan perolehan nilai tersebut dapat dilihat pada tabel berikut.

Tabel 7. Hasil Pengolahan Nilai Keterampilan Siklus II

\begin{tabular}{|c|l|c|c|}
\hline \multirow{2}{*}{ No } & \multicolumn{1}{|c|}{ Uraian } & \multicolumn{2}{c|}{ Frekuensi } \\
\cline { 3 - 4 } & & Siklus I & Siklus II \\
\hline 1 & Peserta & 36 & 36 \\
\hline 2 & Peserta didik tuntas & 24 & 33 \\
\hline 3 & Peserta didik tidak tuntas & 77,78 & 3 \\
\hline 4 & Nilai rata-rata kelas & 66,67 & 90,56 \\
\hline 5 & Persentase ketuntasan & \multicolumn{2}{c}{} \\
\hline
\end{tabular}


Berdasarkan perolehan nilai keterampilan siklus II seperti table 4.13 dapat dilihat bahwa dari 31 peserta didik yang mengikuti ujian, 10 peserta didik atau 32\% tidak tuntas dan 21 peserta didik atau $68 \%$ tuntas. Hasil pengolahan nilai diatas dapat dilihat pada grafik 6 berikut:

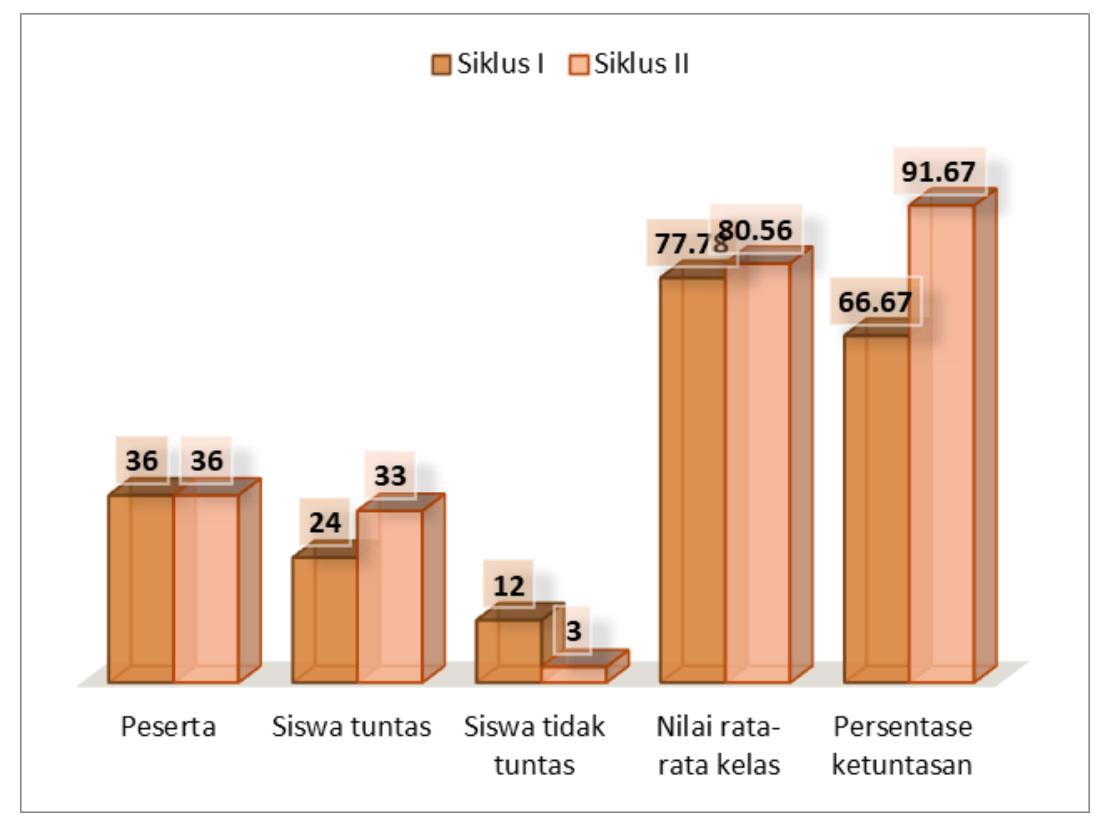

Grafik 6. Nilai Keterampilan Siklus II

Perolehan nilai siklus I dan siklus II menunjukkan adanya peningkatan hasil belajar peserta didik. Persentase nilai pengetahuan peserta didik yang tuntas meningkat dari $69,44 \%$ pada siklus I menjadi $94,44 \%$ pada siklus II. Persentase nilai keterampilan peserta didik yang tuntas meningkat dari $66,67 \%$ pada siklus I menjadi $91,67 \%$ pada siklus II. Sebaliknya, peserta didik yang tidak tuntas persentasenya menurun. Untuk nilai pengetahuan rata-rata kelas 79,72 pada Siklus I menjadi 85 pada Siklus II sedangkan untuk nilai keterampilan rata-rata kelas 77,78 pada siklus I menjadi 80,56 pada Siklus II. Berdasarkan perolehan nilai pada siklus II dapat diartikan bahwa implementasi pembelajaaran model Abad ke-21 Metode Blended Learning cukup efektif dalam pembelajaran matematika untuk meningkatkan hasil belajar.

\section{Diskusi}

\section{Hasil Belajar Pengetahuan}

Hasil belajarpengetahuan yang diperoleh setelah melakukan penelitian ini penulis sajikan pada tabel berikut:

Tabel 8. Perbandingan Hasil Belajar Kompetensi Pengetahuan

\begin{tabular}{|l|l|l|l|l|}
\hline \multirow{2}{*}{ No } & \multirow{2}{*}{ Uraian } & \multicolumn{3}{c|}{ Nilai Pengetahuan } \\
\cline { 3 - 5 } & & Pra Siklus & Siklus I & Siklus II \\
\hline 1 & Jumlah PD mengikuti Tes & 36 & 36 & 36 \\
\hline 2 & Jumlah PD yang telah tuntas & 13 & 25 & 32 \\
\hline
\end{tabular}


Melalui Pendekatan Saintifik Model Pembelajaran Abad Ke-21 Metode Blended Learning untuk Meningkatkan Hasil Belajar Peserta Didik Mata Pelajaran Matematika Kd 3.2/4.2 Pokok Bahasan Sistem Persamaan Linear Tiga Variabel Di Kelas X.IS.1 Man 2 Kota Payakumbuh Semester Ganjil Tahun Pelajaran 2021/2022, Dewi Kemala

\begin{tabular}{|l|l|l|l|l|}
3 & Jumlah PD yang tidak tuntas & 23 & 11 & 4 \\
\hline 4 & Rata-rata nilai kelas & 67,08 & 79,72 & 84,17 \\
\hline 5 & Persentase Ketuntasan & 36,11 & 69,44 & 88,89 \\
\hline
\end{tabular}

Jika tabel di atas disajikan dalam bentuk grafik maka dapat dilihat seperti grafik berikut:

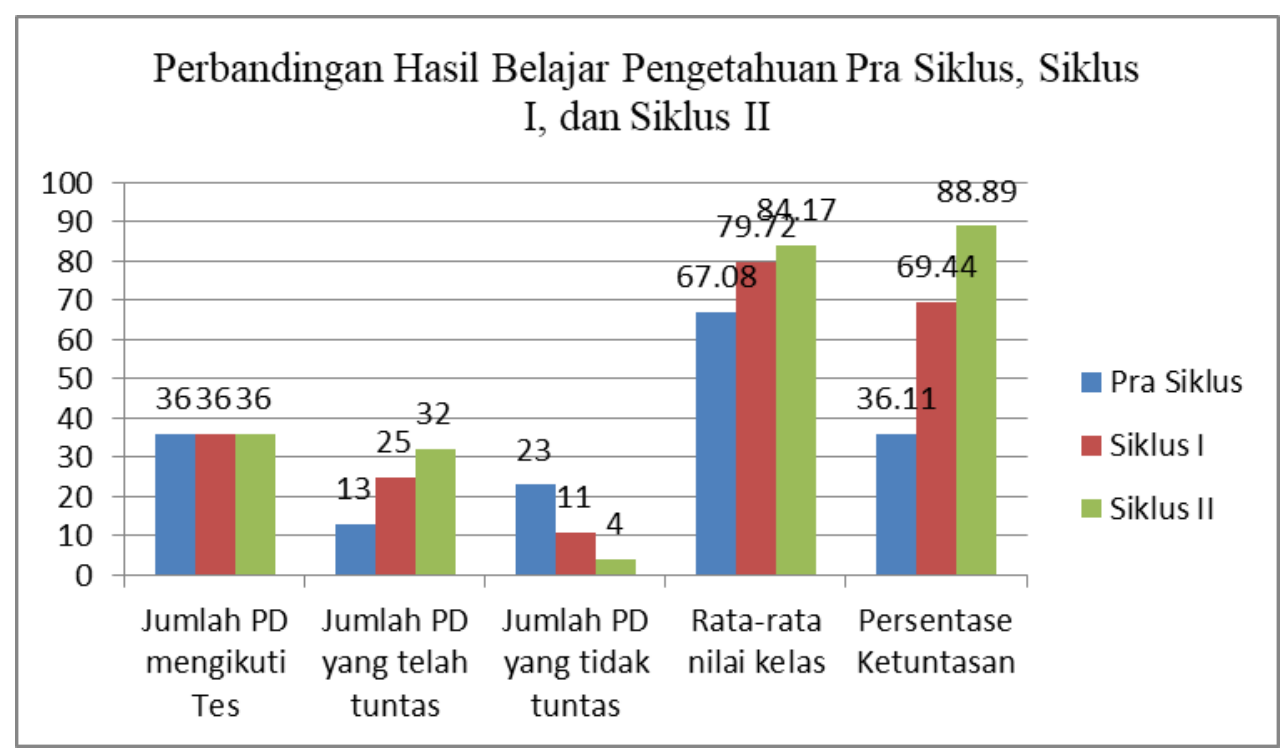

Gambar 7. Perbandingan Hasil Belajar Pengetahuan

\section{Hasil Belajar Keterampilan}

Hasil belajar keterampilan yang diperoleh setelah melakukan penelitian ini penulis sajikan pada tabel 9 berikut:

Tabel 9. Perbandingan Hasil Belajar Kompetensi Keterampilan

\begin{tabular}{|l|l|l|l|l|}
\hline \multirow{2}{*}{ No } & \multirow{2}{*}{ Uraian } & \multicolumn{3}{c|}{ Nilai Keterampilan } \\
\cline { 3 - 5 } & & \multicolumn{1}{|c|}{ Pra Siklus } & \multicolumn{1}{c|}{ Siklus I } & \multicolumn{1}{c|}{ Siklus II } \\
\hline 1 & Jumlah PD mengikuti Tes & 36 & 36 & 36 \\
\hline 2 & Jumlah PD yang telah tuntas & 11 & 24 & 33 \\
\hline 3 & Jumlah PD yang tidak tuntas & 25 & 12 & 3 \\
\hline 4 & Rata-rata nilai kelas & 69,72 & 77,78 & 80,56 \\
\hline 5 & Persentase Ketuntasan & 30,56 & 66,67 & 91,67 \\
\hline
\end{tabular}

Jika tabel di atas disajikan dalam bentuk grafik maka dapat dilihat seperti gambar berikut: 


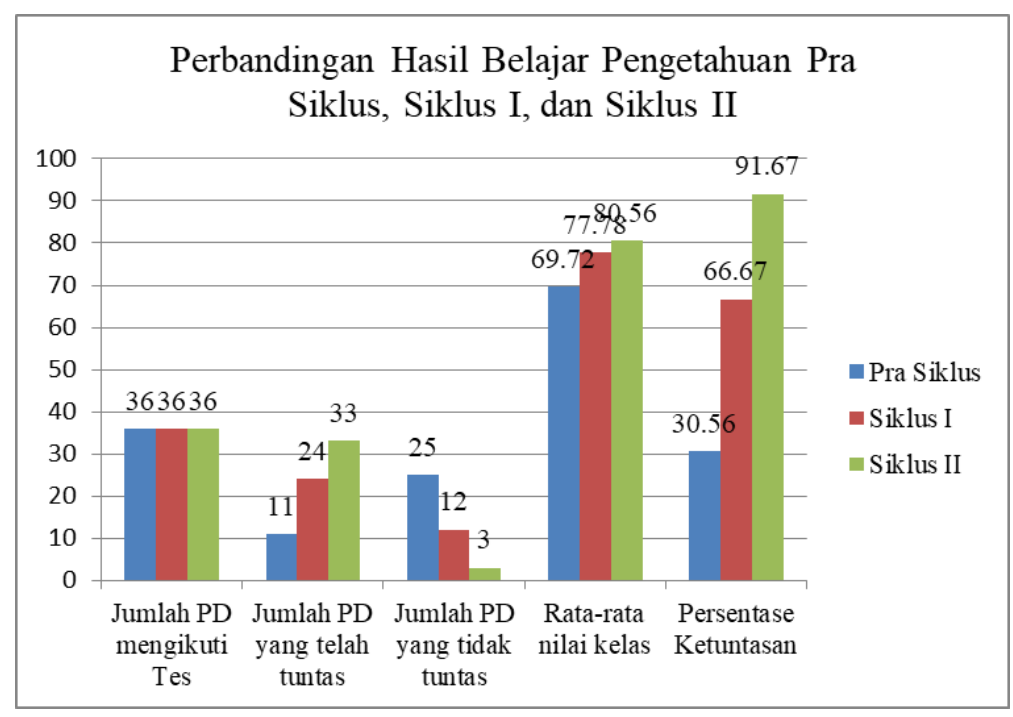

Gambar 8. Perbandingan Hasil Belajar Keterampilan

Hasil penelitian yang telah penulis lakukan, telah memenuhi indicator penelitian dengan perolehan meliputi peningkatan hasil belajar peserta didik dalam proses pembelajaran. Hasil belajar pengetahuan Matematika rata-rata meningkat dari 79.72 pada siklus I menjadi 84.17 pada siklus II, selanjutnya hasil belajar keterampilan meningkat ratanya dari 77.78 pada siklus I terkategori baik naik menjadi 80.56 terkategori baik pada siklus II. Hal ini sebanding dengan penelitian yang telah dilakukan oleh Muhammad Husdi (2020) dengan judul Peningkatan Hasil Belajar Peserta Didik Muatan Pelajaran PAI Materi Pokok Makna Hari Akhir Melalui Pendekatan Saintifik Model Pembelajaran Abad 21 Metode Daring Di Kelas VI SDN 63 Payakumbuh Semester Ganjil TP. 2020/2021, dengan hasil belajar peserta didik pra siklus $67,08=36.11 \%$, Siklus I 79,72=69.44\%, dan Siklus II $84,17=88.89 \%$. untuk ketuntasan belajar keterampilan yaitu pra siklus $69.72=30.56 \%$, Siklus I $77,78=66.67 \%$, dan Siklus II 80.56=91.67\%.

\section{KESIMPULAN}

Hasil yang diperoleh pada prasiklus, siklus I dan siklus II menunjukkan adanya peningkatan. Nilai pengetahuan peserta didik meningkat dari 67,08 pada prasiklus menjadi 79,72 pada siklus I dan menjadi 84,17 pada siklus II. Untuk nilai keterampilan juga meningkat dari 69,72 pada prasiklus menjadi 77,78 pada siklus I, dan menjadi 80,56 pada siklus II. Persentase perolehan nilai pengetahuan peserta didik meningkat dari $36,11 \%$ prasiklus menjadi $69,44 \%$ pada siklus I dan menjadi $88,89 \%$ pada siklus II. Sedangkan persentase perolehan nilai keterampilan juga meningkat dari $30,56 \%$ prasiklus menjadi $66,67 \%$ pada siklus I dan menjadi $91,67 \%$ pada siklus II. Sebaliknya peserta didik yang tidak tuntas persentasenya menurun. Berdasarkan hasil penilaian siklus II tersebut dapat diartikan bahwa implementasi pembelajaran model cukup efektif dalam pembelajaran matematika. Ada beberapa saran yang dapat diberikan dari penelitian ini, antara lain:

1. Untuk lebih meningkatkan keberhasilan kegiatan penelitian Tindakan kelas ini maka diupayakan koordinasi yang lebih baik dari berbagai pihak yang terkait. 
Melalui Pendekatan Saintifik Model Pembelajaran Abad Ke-21 Metode Blended Learning untuk Meningkatkan Hasil Belajar Peserta Didik Mata Pelajaran Matematika Kd 3.2/4.2 Pokok Bahasan Sistem Persamaan Linear Tiga Variabel Di Kelas X.IS.1 Man 2 Kota Payakumbuh Semester Ganjil Tahun Pelajaran 2021/2022, Dewi Kemala

2. Dalam rangka meningkatkan proses pembelajaran perlu dilakukan persiapan yang sangat matang. Terutama dalam menyusun RPP dan mempersiapkan sarana dan prasarana yang memadai.

3. Dalam proses pembelajaran guru tidak terpaku hanya pada satu metode saja.

4. Persiapan-persiapan yang dibuat oleh guru untuk melaksanakan proses pembelajaran agar lebih terfokus pada kegiatan peserta didik atau terpusat pada peserta didik.

\section{REFERENSI}

Abdul Majid. (2008). Perencanaan Pembelajaran. Bandung: PT Remaja Rosda Karya.

Badan Pengembangan SDM Pendidikan dan Kebudayaan. (2014). Materi Pelatihan Guru Implementasi Kurikulum 2013 Tahun 2014 Mata Pelajaran Matematika SMA/SMK. Jakarta: Kemendikbud

Direktorat Pembinaan SMK. (2018). Panduan Penilaian Hasil Belajar dan Pengembangan Karakter Pada Sekolah Menegah Kejuruan. Jakarta: Kemendikbud.

Direktorat Pembinaan SMA. (2017). Implementasi Pengembanagan Kecakapan Abad ke-21 dalam Perencanaan Pelaksanaan Pembelajaran (RPP). Jakarta: Kemendikbud.

Direktorat Pembinaan SMA. (2017). Penyusunan Soal Higher Order Thinking Skill (HOTS). Jakarta: Kemendikbud

Djamarah, Syaiful Bahri dan Aswan Zain.(1997). Strategi Belajar Mengajar. Jakarta; PT RinekaCipta. Indra, Hafrianto.(2019). Optimalisasi Motivasi Dan Hasil Belajar Peserta Didik Mata Pelajaran Bahasa Dan Sastra Jerman Topik Die Schule Melalui Pendekatan Saintifik Model Inquiry Based Learning Metode Diskusi di Kelas X IPS-3 SMA N 3 Payakumbuh Semester Genap T.P. 2018/2019: Payakumbuh: SMA N 3 Payakumbuh

Ni Nyoman Parwati, (2019). Adaptasi Pembelajaran Matematika Di Era Revolusi Industri 4.0 DOI:

10.5281/zenodo.3445646 Prosiding Senama PGRI Volume 1 Tahun 2019 Jurusan Matematika, FMIPA, Universitas Pendidikan Ganesha

Husna (2019). Kontribusi Karakter dan Hasil Belajar Peserta Didik Mata Pelajaran Pendidikan Agama Islam Pokok Bahasan Ketentuan Qurban dan Aqiqah Terhadap Pendekatan Saintifik Model Discovery Learning Metode Simulasi Di Kelas IX.5 Semester Ganjil SMP Negeri 2 Payakumbuh Tahun Pelajaran 2019/2020. Payakumbuh SMP N 2 Payakumbuh id.wikipedia.org > wiki > Pendekatan_saintifik http://repository.umy.ac.id/bitstream/handle/123456789/17111/BAB\%20II.pdf?sequence=6\&isAllow $\mathrm{ed}=\mathrm{y}$.

http://staff.uny.ac.id/sites/default/files/tmp/Penilaian_karakter.pdf. https://ainamulyana.blogspot.com/2020/02/buku-panduan-model-penilaian-karakter.html http://journal.unj.ac.id/unj/index.php/jtp/article/view/15286/8695 
https://www.researchgate.net/profile/I_Ketut_Sudarsana2/publication/344436067_COVID19_Pe rspektif_Pendidikan/links/5f753796299bf1b53e032656/COVID-19-Perspektif-

Pendidikan.pdf\#page $=46$

https://www.stit-alkifayahriau.ac.id/penerapan-sistem-pembelajaran-daring-dan-luring-di-tengah-

pandemi-covid-19/

http://bloktuban.com/2020/12/18/pro-kontra-pembelajaran-tatap-muka-di-masa-pandemi-covid-19/ https://ekofseptilowati.files.wordpress.com/2009/01/transformasi-geometri.doc diunduh tanggal 15012018 pukul 14.32

https://annamatangela.files.wordpress.com/2017/10/modul-transformasi-xi-iba.doc diunduh tanggal

15012019 pukul 14.44

hhttp://ojs.cahayamandalika.com/index.php/jomla/article/view/199 diunduh pada hari Minggu 04

April 2021 pukul 20.10 WIB

Kasmina, Toali, (2014) Matematika Untuk SMK/MAK Kelas XI Jilid 2 : Jakarta Penerbit Erlangga

Keputusan bersama Menteri Pendidikan dan Kebudayaan, Menteri Agama, Menteri Kesehatan, dan

Menteri Dalam Negeri Republik Indonesia Nomor 04/KB/2020 Nomor 737 Tahun 2020 Nomor

HK.01.08/Menkes/7093/2020 Nomor 420-3987 Tahun 2020 Tentang Panduan Penyelenggaraan

Pembelajaran Pada Tahun Ajaran 2020/2021 dan Tahun Akademik 2020/2021 Di Masa

Pandemi COVID-19

Lailatul Faizah, (2020) Implementasi Aplikasi Google Classroom Dalam Pembelajaran Daring

Matematika Masa Pandemi Covid-19 (Studi Analisa Kreativitas Mengajar Guru Matematika di

SMP Negeri 4 Salatiga Tahun Pelajaran 2019/2020 Program Studi Tadris Matematika Fakultas

Tarbiyah dan Ilmu Keguruan (FTIK) Institut Agama Islam Negeri (IAIN) Salatiga

MGMP Matematika Kota Semarang, 2006. Matematika SMA/MA Kelas XII Program Ilmu

Pengetahuan Alam, Semarang: PT Mascom Graphy, Semarang

Muhammad Husdi (2020): Peningkatan Hasil Belajar Peserta Didik Muatan Pelajaran PAI Materi

Pokok Makna Hari Akhir Melalui Pendekatan Saintifik Model Pembelajaran Abad 21 Metode

Daring Di Kelas VI SDN 63 Payakumbuh Semester Ganjil TP. 2020/2021. Payakumbuh SDN

63 Payakumbuh

Permendikbud No. 34 Tahun 2018 tentang Standar Nasional Pendidikan Sekolah Menengah Kejuruan

/ Madrasah Aliyah Kejuruan

Peraturan Dirjen Dikdasmen no. 06/D.D5/KK/2018 tentang Spektrum SMK

Peraturan Dirjen Dikdasmen no. 07/D.D5/KK/2018 tentang Struktur Kurikulum SMK

Peraturan Dirjen Dikdasmen No: 07/D.D5/KK/2018 tentang Struktur Kurikulum Sekolah Menengah Kejuruan (SMK) / dan Madrasah Aliyah Kejuruan (MAK);

Peraturan Dirjen Dikdasmen no. 464//D.D5/KR/2018 tentang Kompetensi Inti dan Kompetensi Dasar Rani Septiana Rismonika, (2020) Implementasi Model Pembelajaran Online/ Daring Terhadap Hasil

Belajar Mata Pelajaran Matematika Kelas VI MI Tarbiyatul Islamiyah Noborejo Tahun 
Melalui Pendekatan Saintifik Model Pembelajaran Abad Ke-21 Metode Blended Learning untuk Meningkatkan Hasil Belajar Peserta Didik Mata Pelajaran Matematika Kd 3.2/4.2 Pokok Bahasan Sistem Persamaan Linear Tiga Variabel Di Kelas X.IS.1 Man 2 Kota Payakumbuh Semester Ganjil Tahun Pelajaran 2021/2022, Dewi Kemala

Pelajaran 2019/2020: Program Studi Pendidikan Guru Madrasah Ibtidaiyah Fakultas Tarbiyah

Dan Ilmu Keguruan Institut Agama Islam Negeri (IAIN) Salatiga

Ridwan Sototoy (2020) : Peningkatan Hasil Belajar Peserta Didik Muatan Pelajaran Seni Budaya

Materi Pokok Gaya Dan Tehnik Bernyanyi Lagu Daerah Melalui Pendekatan Pembelajaran

Abad 21 Metode Daring Di Kelas VII.4 SMP Negeri 9 Payakumbuh Semester Ganjil TP. 2020/2021. Payakumbuh SMP N 9 Payakumbuh

Rochiarti Wiriaatmadja. (2008). Metode Penelitian Tindakan Kelas (PTK) Untuk Meningkatkan Kinerja Guru dan Dosen. Bandung: PT Remaja Rosda Karya.

Risman, Waitlem (2016), Praktik Praktis Penulisan Karya Tulis Ilmiah Untuk Guru: Padang: Kabarita Siti Rofiqoh (2020),Peningkatan Hasil Belajar Peserta Didik Melalui Penerapan Pembelajaran Higher Order Thinking Skills (HOTS) Pada Mata Pelajaran Matematika Materi Bilangan Berpangkat Dengan Model Discovery Learning di SMP Negeri 20 Kota Bogor. Bogor: SMP Negeri 20 Kota Bogor

Sukidin, Basrowi, Suranto. (2008). Manajemen Penelitian Tindakan Kelas. Surabaya: Insan Cendekia. Sartono Wirodikromo, 1994. Matematika Untuk SMU Kelas 3, Program IPA, Caturwulan 2, Penerbit Erlangga

Surat Edaran dari Kemendikbud Nomor 15 Tahun 2020 tentang Pedoman Penyelenggaraan Belajar Dari Rumah Dalam Masa Darurat Penyebaran Covid-19

Surat Edaran dari Gubernur Sumatera Barat Nomor 900/1961/Disdik-2020 tanggal 30 Desember 2020 tentang Penyelenggaraan Pembelajaran di Satuan Pendidikan pada Semester Genap Tahun Pelajaran 2020/2021 Pandemi Covid-19

Tim Pusat Penilaian Pendidikan. (2019). Model Penilaian Karakter. Jakarta: Kemendikbud

(2014). Pendekatan Saintifik dan Model Pembelajaran Kurikulum 2013.http://www.matematrick.com/2014/11/pendekatan-saintifik-dan-model.html (diakses tanggal 13Januari 2019). 